\title{
Becoming a bwana and burley tobacco in the Central Region of Malawi
}

\author{
Prowse, Martin
}

Published in:

Journal of Modern African Studies

DOI:

10.1017/S0022278X09990139

Publication date:

2009

Document version

Publisher's PDF, also known as Version of record

Citation for published version (APA):

Prowse, M. (2009). Becoming a bwana and burley tobacco in the Central Region of Malawi. Journal of Modern African Studies, 49(4), 575-602. https://doi.org/10.1017/S0022278X09990139 


\title{
Becoming a bwana and burley tobacco in the Central Region of Malawi*
}

\author{
Martin Prowse \\ Institute of Development Policy and Management (IOB), University of Antwerp, \\ Prinsstraat 13, B-2000 Antwerpen, Belgium \\ Email: martin.prowse@ua.ac.be
}

\begin{abstract}
A B S T R A C T
Smallholders now grow most of Malawi's main export crop - burley tobacco. Based on nineteen months' fieldwork in the Central Region, this article offers a sociological interpretation of why some smallholder growers spend a proportion of burley income on conspicuous consumption in rural towns and trading centres. This practice can be seen as a form of inculcated behaviour whereby smallholders reproduce elements of one model of success in this region: that of the Malawian tobacco bwana (boss/master). The article discusses implications from this form of potlatch behaviour by describing the contrasting fortunes of two non-farm rural enterprises, examining data on how tobacco production and 'cooling off' is viewed by wives, and comparing the crop preferences of husbands and wives. It concludes by suggesting that the concept of conspicuous consumption may provide an alternative prism to the instrumental lens of neo-patrimonialism through which to view apparently unintelligible investment decisions in African economies.
\end{abstract}

\section{N T R O D U C T I O N}

Malawi is the world's most tobacco-reliant economy, with the crop contributing over 6o \% of annual export earnings, most of which come from one type: burley tobacco. Malawi's dependence on fodya (tobacco) is not

* The research for this paper was conducted whilst I was a $\mathrm{PhD}$ candidate at the University of Manchester. I gratefully acknowledge Economic and Social Research Council funding, and my affiliation to the Centre for Social Research, Zomba, and the National Smallholder Farmers' Association of Malawi (NASFAM). I thank Juveta Nkhata and Sirjent Saka for excellent research assistance, Jens Andersson and Richard Sherrington for their comments, and Jan Kees van Donge for his enthusiasm in studying the sociology of economic life. Thanks are also due to the anonymous reviewers whose comments have improved the paper considerably. 
new, as the country has relied on semi-processed tobacco exports for most of the last century (see McCracken I983; Ng'ong'ola I986; Wilshaw I994). But what is relatively new is that smallholders now grow most tobacco, in contrast to the first three decades after independence when the two premier types of tobacco - burley and flue cured - were exclusively reserved for the estate sub-sector (defined not by size, but by land tenure: see Ng'ong'ola I986).

During the Malawi Congress Party (MCP) era which ended in I994, the political elite became heavily involved in estate tobacco production (see Kydd \& Christiansen 1982; McCracken 1984; van Donge 2002a). The scale of estates changed considerably during this period. Through the ig6os the Farmers' Marketing Board (which became the Agricultural Development Marketing Corporation, ADMARC, in I97I) bought estates abandoned by European settlers, sold them to the political elite, and provided loans and management services (Kydd I984). Estate production was particularly attractive after Rhodesia's Unilateral Declaration of Independence in 1965 , and the imposition of sanctions in 1966 , which increased demand for Malawian flue-cured tobacco (ibid.). ${ }^{1}$

During the I970s, the political elite and government-affiliated institutions created and took control of dozens of large-scale estates, and grew fluecured and burley tobacco using labourers and tenants respectively (see Kydd \& Christiansen i982; Mkandawire et al. I990; van Donge 2002a). ${ }^{2}$ This estate expansion was based partly on the alienation of communal land, and partly on the compulsory purchase of European-owned estates (McCracken 1984; van Donge 2002a). For example, many Europeans in the Central Region had their estate licences revoked in 1970 (Thomas I975). ${ }^{3}$

At the centre of estate expansion at this time was Press Corporation. As van Donge (2002b: 657) highlights, 'Press farmed tobacco, Press traded tobacco, and Press was instrumental in financing the growing of tobacco'. For example, the two divisions of Press Agriculture (General Farming, jointly owned by President Banda and the FMB; and Press Farming, owned by the Malawi Congress Party) increased estate holdings considerably through the ig7os. Press Corporation took a $42 \%$ stake in a key leaf merchant company, Limbe Leaf, controlled by Universal Leaf (the world's largest tobacco merchants), and a shareholding in the Commercial Bank of Malawi, a key source of finance for estate expansion (ibid.). However, by the end of the ig7os the close relationships between key economic institutions (such as Press Corporation, ADMARC and the Commercial Bank), which had sustained growth in large-scale tobacco estates in the I970s, came under strain (see van Donge 2002a; Harrigan 


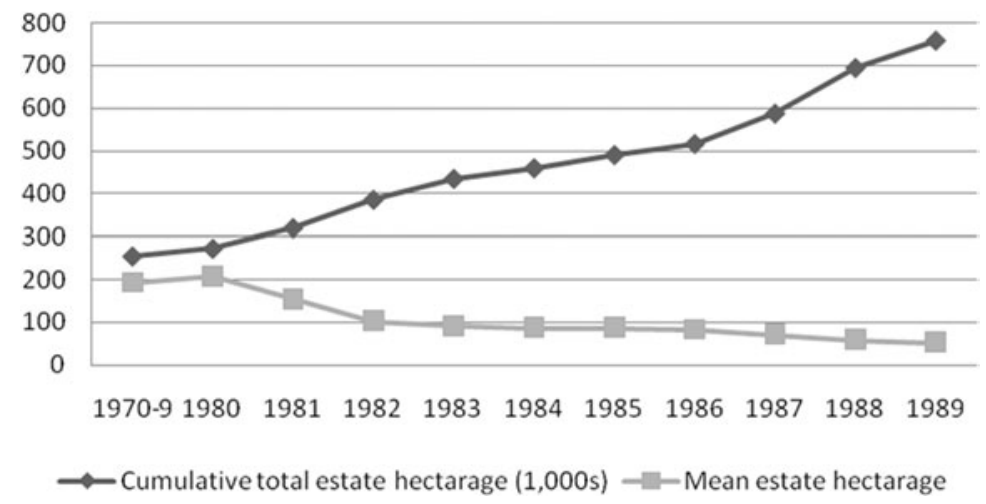

FIGURE I

Small-scale estate expansion in the ig8os. Source: Conroy I993.

200I), and estate expansion in the next decade was on an altogether different scale.

Estates in the I980s became much smaller, with mid-level civil servants, estate managers and 'graduating' smallholders obtaining leasehold tenure over tracts of communal land (see Conroy 1993; Sahn \& Arulpragasam I99I). The rapid increase in the number and area of estates, and their decreasing mean size, is illustrated in Figure I.

Whilst new estates were opened in the north of the country, estate expansion in the I980s was fastest in the Central Region (Sahn \& Arulpragasam I99I : I5), and almost entirely based on tenant production of burley tobacco (Kydd \& Hewitt 1986). As on large-scale estates growing burley, this often took the form of the visiting tenant system, where migrant (or local) households were loaned inputs and basic food rations at the start of the agricultural season (October/November), with their cost (plus interest) deducted from the fixed prices paid by the estate owner for the cured tobacco leaf (set nationally by the Tobacco Association of Malawi-TAMA). Such tenants rarely managed to save income or accumulate assets, as TAMA prices were substantially below auction floor prices.

But from i990 onwards, and especially after 1994, tobacco production and marketing in Malawi underwent substantial reform, allowing smallholders to legally grow and market burley tobacco. ${ }^{4}$ The aim of the reform process was to improve smallholders' incomes and food security, and boost the non-farm rural economy (Orr 2000; Tobin \& Knausenberger 1998; 


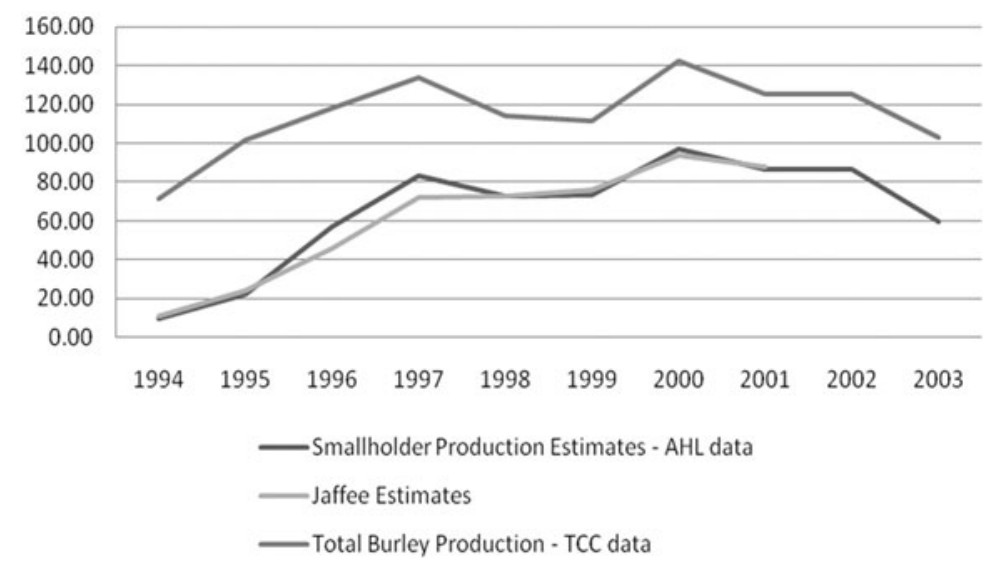

FIGURE 2

Smallholder Share of Burley Production I994-2003 (millions of kgs). Sources: Auction Holdings datasets, Tobacco Control Commission datasets, Jaffee 2003 .

USAID I994; World Bank I994). ${ }^{5}$ Smallholders responded enthusiastically to this opportunity. For example, the number of registered smallholder burley clubs increased from 502 in 1990 to $2,45^{8}$ in 1995 (the last year when clubs were allocated production quotas), to 29,225 in 2000, before declining to I7,00 in 2003 (Tobacco Control Commission data). Figure 2 shows estimates of the smallholder share of total burley production from I994 to 2003 (including estimates of the proportion of smallholder-grown burley marketed through an intermediate buyer or estate registration number). ${ }^{6}$ It suggests that smallholder burley production increased from about 10,000 tons in 1994 to over 97,000 tons in 2000, before declining to about 6o,ooo tons in 2003. These estimates suggest that between 1997 and 2003 about $60 \%$ of total national burley production (averaging about 120,000 metric tonnes) was grown by smallholders. ${ }^{7}$

But although smallholder burley production has increased growers' incomes (for example, see Carvalho et al. I993; Orr 2000; Zeller et al. 1998), little is known about smallholders' expenditure patterns from burley. This is significant because, as the World Bank (I997: iv) notes, 'smallholder profits from burley sales have provided the largest ever cash injection of income in rural Malawi'. Whilst some studies highlight how smallholder burley production led to multiplier effects in local economies (Orr 2000; Orr et al. 200I; Zeller 1997), few studies have provided clear details on how 
TABLE I

Burley tobacco sold through smallholder registration number by region

\begin{tabular}{|c|c|c|c|c|c|c|}
\hline & \multicolumn{2}{|l|}{ I997 } & \multicolumn{2}{|l|}{2000} & \multicolumn{2}{|l|}{2003} \\
\hline & $\begin{array}{c}\text { S/holder sales } \\
\text { tonnes }\end{array}$ & $\%$ & $\begin{array}{c}\text { S/holder sales } \\
\text { tonnes }\end{array}$ & $\%$ & $\begin{array}{c}\text { S/holder sales } \\
\text { tonnes }\end{array}$ & $\%$ \\
\hline Northern Region & 4,460 & $26 \cdot 6$ & II, 876 & $27 \cdot 9$ & $\mathrm{I}_{5}, 883$ & $33 \cdot 7$ \\
\hline Central Region & 5,918 & $35^{\cdot 2}$ & 20,459 & $48 \cdot \mathrm{I}$ & $2 \mathrm{I}, \mathrm{IO} 3$ & $44^{\cdot} 8$ \\
\hline Southern Region & $6,4^{12}$ & $38 \cdot 2$ & IO,I9O & 24 & IO,I29 & $2 \mathrm{I} \cdot 5$ \\
\hline Total & I $6,79^{\circ}$ & 100 & $4^{2,525}$ & IOO & $47, \mathrm{II} 5$ & IOO \\
\hline
\end{tabular}

Source: Auction Holdings datasets.

or where burley income is spent. There are exceptions. One is the longitudinal work of Peters in Zomba district (for example, see Peters I996, 1999, 2006; Peters et al. I989). In this work we can glean that burley income is spent on building materials, clothes, fertiliser and setting up small businesses. But however insightful these studies are, they tell us little about the manner in which most smallholder burley income is spent. This is because smallholder burley production is now mainly located in the Central and Northern Regions, not the Southern Region. To illustrate this point, Table I shows the amount of burley tobacco sold on the auction floors in I997, 2000 and 2003 through a smallholder registration number by region. The Southern Region's share of smallholder burley production declined from $38 \cdot 2 \%$ in 1997 to $21.5 \%$ in 2003 , much lower than the $33.8 \%$ from the Northern Region, and $44 \cdot 8 \%$ from the Central Region. ${ }^{8}$

In addition, there is an important reason why a high proportion of smallholder burley was grown in the Southern Region in the early years of burley reform. As burley production was framed in terms of poverty alleviation and improving food security, the main donor agencies involved in the reform process (USAID and the World Bank) ensured that $75 \%$ of smallholder production quotas were allocated to rural households with less than I hectare (World Bank i994). This took the form of geographical targeting, and meant that in the early ig9os almost $50 \%$ of smallholder quotas were allocated to extension planning areas in the Southern Region, where landholding sizes are smallest. But such geographical targeting did not ensure that burley quotas were received by poor, land-constrained farmers, as intended by the reform process. Instead, quotas and early burley clubs were dominated by the upper strata of rural communities (see Orr 2000; Peters 1996; Tobin \& Knausenberger 1998). As the pace of burley reform increased, in 1996 the quota system was replaced by a registration 
system which facilitated access to the auction floors for all smallholder growers. Table I suggests that smallholders in the Central and Northern Regions responded most enthusiastically to this opportunity. In this respect, it may be unwise to extrapolate data on how burley income is spent, and on the effects of burley production more broadly, from the Southern Region to the centre and the north. This is especially the case if one considers particular characteristics of the Southern Region which are not replicated in the other regions: the smaller landholding sizes, the easier access to urban markets, and the cross-border trade with Mozambique (Orr \& Mwale 2001; Orr et al. 200I; Whiteside I998).

This paper aims to aid understanding of smallholder expenditure patterns and practices associated with burley income in the Central Region of Malawi. It does not describe survey expenditure data, but takes a sociological perspective and offers data generated from a variety of research methods conducted during nineteen months of fieldwork between August 2002 and June 2004. Fieldwork took place in four different stages: an initial period of four months based in Lilongwe; a subsequent period of six months when the author was introduced into a rural community and began micro-level research; an intensive eight-month period when most of the micro-level research was conducted; and a final period of one month in Lilongwe. Specific locations for the research were not predefined, but emerged from the research process. In Lilongwe, research locations included air-conditioned bureaucrats' offices, seminars at hotels, and amongst the tobacco bales on the auction floors. At the district level, research was conducted in offices of agricultural and government institutions, as well as in bars and restaurants where civil servants, wage earners and tobacco farmers socialised. The location for micro-level research was guided by spatial analysis to find an area of concentrated burley production, and methods included participatory rural appraisal techniques, household surveys in four villages (with husbands and wives interviewed separately and simultaneously), life history interviews, and focus group discussions (including the presentation of preliminary findings to participants). In addition, the research involved the long-term direct observation of social practices - in Kasungu town, in a rural trading centre and, to a lesser extent, in the four village communities. The commitment to the ethnographic method mainly informs the first two sections of the paper. Data from life history interviews, a household survey, and focus group discussions, mainly inform the last two.

Using data from this mix of research methods, the paper offers a sociological interpretation of why some smallholder tobacco growers in the Central Region immediately spend a proportion of burley income on 
alcohol and consumer goods in rural towns and trading centres, known as kuziziritsa ku khosi (lit. 'to cool the throat', but referred to as 'cooling off'). It argues that this practice is a form of conspicuous consumption through which smallholders, in an expression of inculcated behaviour, attempt to attain the status of a tobacco bwana (boss/master). The argument is made by constructing an idealised 'cultural model', mainly from ethnographic data. The first two sections of the paper show how at the national and district levels the tobacco industry in Malawi reifies the 'cultural model' of the tobacco bwana, and how the behaviour of smallholder growers in the Central Region reproduce key elements of this model. The last two sections of the paper discuss some implications of this form of conspicuous consumption: first, by describing the contrasting fortunes of two non-farm rural enterprises; and second, by discussing limited data on how tobacco production and 'cooling off' is viewed by wives, and the crop preferences of both husbands and wives. The paper concludes by suggesting that the concept of conspicuous consumption may provide an alternative prism through which to view apparently unintelligible investment decisions in African economies to the instrumental lens of neo-patrimonialism.

CONSTRUGTING THE 'CULTURAL MODEL' OF THE T OBACGO $B W A \mathcal{N} A$

This section draws out similarities in the culture of the national-level tobacco industry in Malawi, and the status of estate owners in Kasungu district, to offer a stylised description of the 'cultural model' of the Malawian tobacco bwana. It highlights how tobacco production in Malawi is influenced by a racialised, gendered and class-based set of norms and practices.

The starting point in this exercise is to recall that the reservation of burley and flue- cured tobacco for estates, only rescinded in the I990s, was originally based on the racialised separation of 'light' tobaccos, such as flue-cured, for whites, and 'dark' tobaccos, such as fire-cured, for black Africans. ${ }^{9}$ It was also partly based on a colonial belief that light tobaccos were too technical for Africans to grow (see Wilshaw I994). The tobacco industry in Malawi is still to some extent imbued with such colonial-style views regarding white racial superiority and bigotry.

These features are brought into relief at the annual tobacco seminar, when all the different stakeholders in the industry come together around a conference table. The constituency at the table is almost exclusively male. Many of the participants are notable by their bulk, smart suits, and number of cigarettes they smoke, thus displaying their attachment to the commodity that pays their bills. Most of them are black Malawians, apart 
from one side of the table where white estate owners sit adjacent to white tobacco leaf company managers. The main tobacco leaf merchants are almost exclusively white, from Malawi, South Africa and Zimbabwe. ${ }^{10}$ The leaf companies hold great power in the industry due to their close relationships with, and contractual obligations to, international cigarette manufacturers, and their control over the capital goods which process tobacco before export. ${ }^{11}$

The difference between white estate owners and white leaf company managers became clear during the course of the seminar. Whilst white estate owners conversed (sometimes in chiChewa) and socialised with all participants, the leaf company managers kept themselves to themselves, ensuring physical and social segregation: they stayed at a different hotel, ate meals separately, and failed to participate in social functions. Whilst many open-minded African whites work in the tobacco industry, particular leaf companies still have a reputation for racism. In addition, the culture of leaf company bosses in Lilongwe is particularly macho: de rigueur elements include huge jeeps, short-sleeved blue shirts, brais (barbeques), Castle lager, blue label Johnnie Walker whisky and Peter Stuyvesant cigarettes. A handful of senior black Malawian employees in the leaf companies embrace this white tobacco culture, exhibiting similar practices, clothing and accessories to their better-paid colleagues (see Fanon ig68; Rutherford 200I).

Black Malawian tobacco culture in Lilongwe is likewise very macho and alcohol-dominated. It is also strictly differentiated along class lines. The black Malawian managerial strata within tobacco institutions are very much part of the political elite and fraternise in these circles. Black Malawian mid-level managers and leaf buyers are part of the middle class in Lilongwe, often frequenting bars and clubs in town, and straddle paid employment with farm and non-farm business activities. The mass of those employed by the tobacco industry - labourers - form one of the most significant industrial workforces in the country, and in their spare time many labourers can be found in the Chibuku bars alongside the auction floors and around the city.

In some ways, chauvinism in the industry reflects its history: throughout the last century, tobacco production for export has been seen as an exclusively masculine endeavour (see Wilshaw I994). As part of the implicitly male colonial project of conquering distant lands, tobacco production was seen as an example of the 'chaos' of the African bush being wrenched into order and brought under productive control. In the post-colonial era, tobacco production by the male black Malawian elite was part of the wider pan-African, and predominantly masculine, process of nation-building 
and self-determination (see Mkandawire 2005). Tobacco in Malawi is a man's world. A clear indication can be gleaned from a cursory look at the auction floors during any sale: it is highly unusual to find women working in the tobacco industry other than in a secretarial capacity. ${ }^{12}$

In addition to race and gender, tobacco production in Malawi has also, until recently, been based on a strong class division. From colonial thangata labour regimes in the Southern Region, to the visiting tenant system initiated by I. Conforzi in the I950s, and institutionalised by the MCP from the I970s, tobacco production has always relied on controlling and exploiting labour. During the large-scale estate expansion of the late ig6os and I970s, this was either direct wage labour to grow flue-cured tobacco (due to the high labour and capital requirements of this crop), or visiting tenants for burley production. Estate owners' ability to offer employment (in the form of annual tenancies or ganyu-piecework), the security implications of such relationships, and estate owners' political and business connections, have contributed to them (in the Central Region at least) being accorded high social status within rural areas.

A brief description of the two largest estates, and one small-scale estate owner, in the area of Kasungu district where most micro-level fieldwork was conducted helps to illustrate this point. As we saw earlier, the political elite and government-related organisations took over dozens of large-scale tobacco estates in the I970s. One example is the Chimbwazi estates, the largest in the area, opened by A. F. Barron in the I950s but taken over by President Kamuzu Banda, in a personal capacity, in about i97o. Kamuzu extended these estates, displacing villages from communal land, built fluecured barns on two of the three estates, and started to grow flue-cured tobacco (tenants grew burley on the third). In about I975 Kamuzu handed control of the estates to his nephew's company (part of the Chamwavi Group, closely aligned to the president's family's business interests). For the next two decades, the estates grew flue-cured and burley tobacco, employing both migrant and local workers (although the size of the estates decreased as a portion returned to the traditional authority due to encroachment by land-scarce villagers). By the late I99os the Chamwavi Group was in financial difficulties, and the estates were subsequently leased to ADMARC and a tobacco leaf company. ${ }^{13}$

The owner of the second largest estate in the area also held a position of considerable power. The Sesa estate opened around I975, and was owned by a senior figure in the Malawi Young Pioneers (MYP), the paramilitary youth league of the Malawi Congress Party. The 30o-hectare estate grew flue-cured tobacco using direct labour, with managers and some workers coming from MYP training centres. Again, this estate ran into financial 


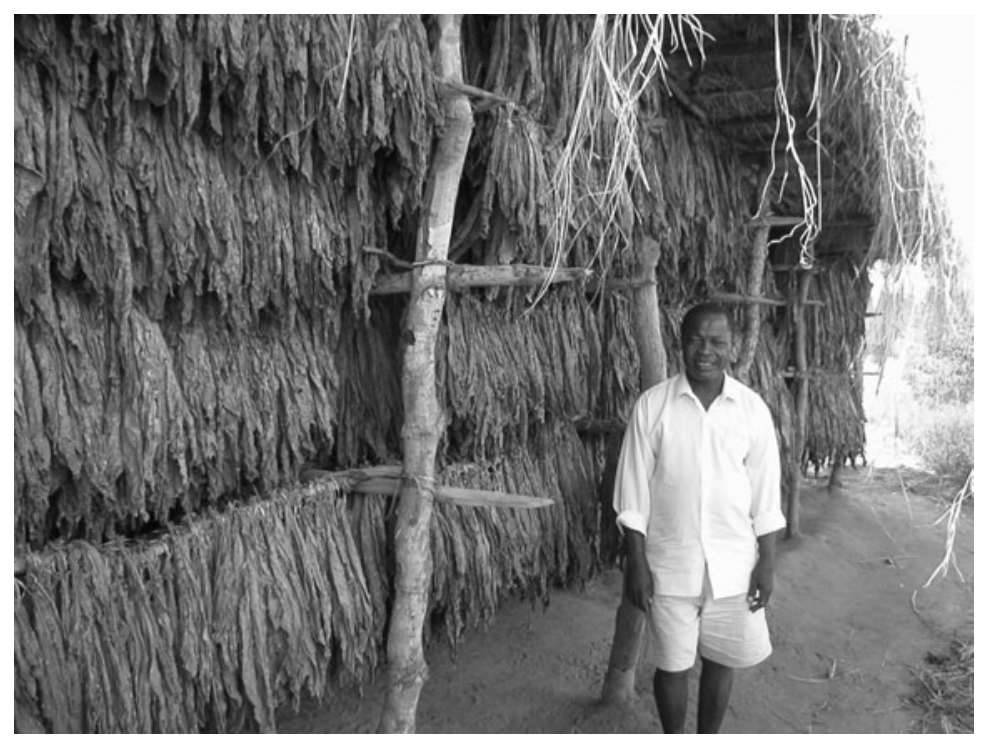

FI G URE 3

Bishopo Tsoka (pseudonym).

difficulties at the end of the ig9os and was later leased by a tobacco leaf company.

The high social status of estate owners is also reflected in the brief biography of one small-scale estate owner who started growing burley in the Ig8os. Bishopo Tsoka (pseudonym) was born in rural Kasungu as a son to a labour migrant who worked in the mines in South Africa. After finishing school he married in I952, and farmed maize and groundnuts. From crop sales to the FMB he set up a small tea room and grocery close to his village, and married a second wife in 1956 . Between I956 and 1981 he farmed, ran a grocery and, as a sing'ang'a (herbalist), became renowned for his powerful mankwala (medicine). In the early ig8os Mr Tsoka's fortunes improved: he became a chairman of a National Bank farming club, and later leased his first estate. Through the ig8os he opened three further estates, and up until 2004, with the assistance of his wives and children, managed up to a hundred tenants per year and invested in maize mills, vehicles and grocery stores (see Figure 3, which shows Bishopo in front of his huge burley barn). From the perspective of a smallholder (who may well have worked on these estates), all of these estate owners held positions of great power and prestige, albeit in very different ways. 


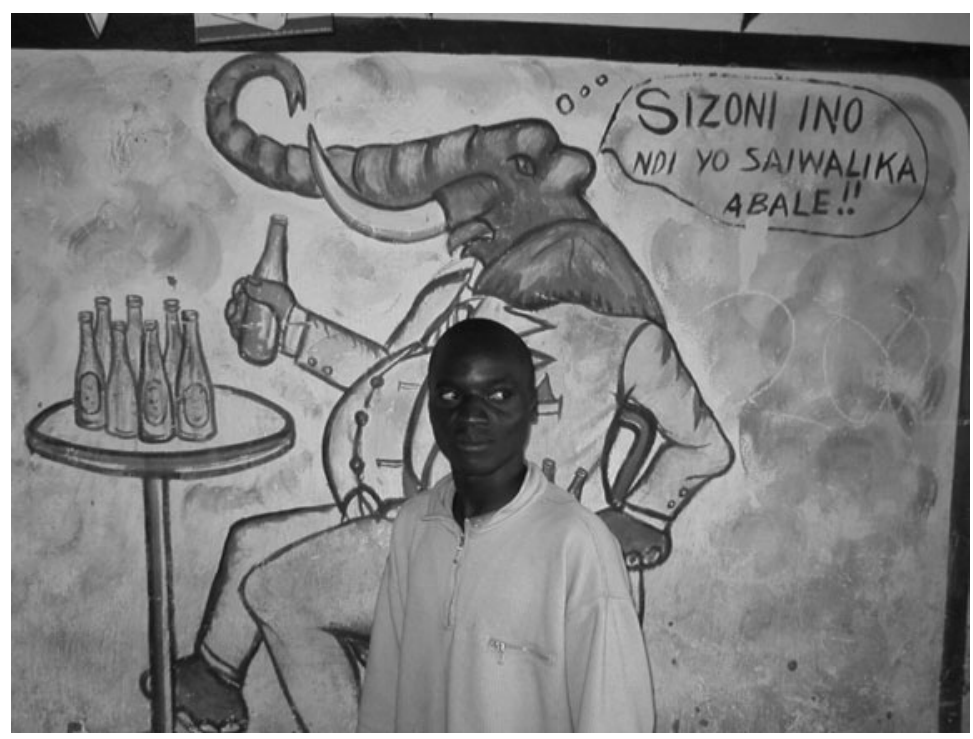

F I G URE 4

Sizoni ino ndi yosaiwalika abale (this season is unforgettable my friends).

This national and district-level analysis allows us to construct a highly stylised 'cultural model' of the black Malawian tobacco bwana. A clear illustration of this model can be found in a bottle store on the tarmac road to Kasungu town. Along one wall of the bottle store is a painting, framed by tobacco leaves. In Figure 4 an overweight njobvu (elephant) is sitting at a table exclaiming: 'This season is unforgettable my friends'. The table is full of bottles of Carlsberg green, a premier Malawi-brewed beer. Bottles stick out of the pockets of his suit. Wealth and status are represented in his huge physical size, his attire and his ostentatious purchases. The next section suggests that this model of 'success' - that of the black Malawian tobacco bwana - has percolated into norms and practices in the Central Region, and that some smallholders attempt to (temporarily) attain the same status through the practice of kuziziritsa ku khosi or 'cooling off'.

B E G OMING A $B W A \mathcal{N} A$ : GOOLING OFF IN KASUNGU TOWN

Burley tobacco production pervades village life in rural Kasungu through the crop marketing season of April-August: bales of tobacco are shunted by ox carts; men, women and children tie burley leaves under barns; Zambian traders lodge at grocery stores, illegally buying burley for 
shipment across the border. However, an extended residence in rural Kasungu provided no immediately apparent expression of a smallholder tobacco culture equivalent to the obvious racially and class-segmented culture in Lilongwe. The main reason was because this culture is expressed not in rural areas, but in town.

From September to March, visitors to the major urban centre in the district-Kasungu boma-find a subdued town housing the requisite governmental and financial institutions, trading stores, shops, stalls, in addition to a smattering of NGOs. However, entering the same place in the crop marketing season, visitors are greeted by an altogether different scene: streets are filled with vendors and hawkers plying their wares, freshly painted shops advertise their commodities on the pavements, minibus conductors compete vigorously for passengers, and the markets, restaurants, bottle stores and rest houses are all doing brisk business. As a hot spot for burley production, tobacco money percolates around Kasungu, attracting people, produce, traders and entertainment.

When collecting tobacco income from the bank in Kasungu, some smallholder burley growers (always men), dressed in their finest clothes, stay in town for a while 'cooling off'. During this time they buy consumer goods such as radios, watches, branded clothing, smart shoes, bags and stereos, and replicate the actions of the njobvu in Figure 4 by consuming as much Carlsberg Green as possible (instead of drinking the cheaper and conventional rural beer, Chibuku). ${ }^{14}$ While it is hard to generate data on the prevalence of this practice, survey data on 120 smallholder households offer some indication..$^{15}$ These data suggest that a quarter of the forty-seven smallholders who collect tobacco income from a bank in Kasungu (or I0 \% of smallholders surveyed) stay in town for between two and thirty days after collecting their money (with an average stay of ten days, and a median figure of one week). ${ }^{16}$ Although practised by a minority of burley growers, if this prevalence of 'cooling off' is the same across rural Kasungu, it suggests a figure of about Io,ooo smallholders per year in this one district. ${ }^{17}$

Importantly, the consumer choices of these tobacco growers are striking because they are practised in an intentionally conspicuous and provocative way: Carlsberg beer was bought by the crate, not by the bottle; and fashionable clothes and accessories were often flaunted and paraded. The extent to which smallholders 'cooled off' in town seemed to far exceed the means at their disposal. The generic practice of kuziziritsa ku khosi was described by one smallholder in the following way:

A husband hears that his bales of burley have been sold on the auction floors, and he arranges to go into town to collect his money. When he has collected his money from the club treasurer and joined his friends, he says 'no, let us just take 
Green because this time it is tobacco time - I have been working hard in my tobacco fields for six months so now it is the time for enjoying'. So after Chibuku he buys bottles of Green, and then more as it tastes so good. Instead of taking the bus home with relish for his wife to prepare for dinner, he takes more Green with his friends, and spends the night enjoying himself in town drinking and dancing. When he wakes up in the morning in a rest house he has spent over Kw2,ooo. On leaving the rest house he walks up the main street passing the bottle stores and nightspots of the night before, then the vendors and hawkers lining the street. He starts looking for a gift for his wife so that his return to the $m u d z i$ (village) will be smoother. In the market he buys a chitenje for Kw40o. To regain some strength he then takes nsima from a restaurant, and on his way to the bus station he stops for one packet of Chibuku. Here he meets some friends from the previous night, and as Chibuku is usually drunk in a group, more Chibuku arrives and before long the headache from the previous night has gone. The day leads into night and the drinks change from Chibuku to Greens, and later he will be dancing again in the nightclubs. The next day maybe he returns home carrying meat, paraffin, clothes for the children and the chitenje. With two bales of tobacco still in the shed, the money is forgotten about. However the problem comes when the smallholder is borrowing money to buy fertiliser the following December. ${ }^{18}$

Branded Carlsberg beer, especially Carlsberg Green, appears central to the practice of kuziziritsa ku khosi. In rural Kasungu it was widely perceived that Carlsberg Green tastes like tobacco, and some believe it is made from tobacco. ${ }^{19}$ Clothing and style are also important elements of kuziziritsa ku khosi. $^{20}$ While older men would dress smartly, reminiscent of the suits popular during the MCP era (as seen in Figure 4), younger generations invest in branded jeans, $t$-shirts and accessories. ${ }^{21}$

A further element of 'cooling off' involves longer-distance migrants arriving from various parts of the country. As tobacco money circulates around Kasungu, the town becomes the destination for an influx of mahule (prostitutes), many of whom exhibit urban-based fashion accessories and styles - such as hair extensions and tight trousers - distinguishing them from rural women. Business is brisk with smallholders 'cooling off' in town. ${ }^{22}$ The seasonal dimension to prostitution in Kasungu is evidenced by data from Population Services International (PSI), a USAID-funded agency. PSI distributes Chishango condoms throughout Malawi, and data on sales can be used as crude proxy for sexual activity. Data for 2003 show that sales in Kasungu town increased by over a factor of four in the crop marketing season compared with other times of the year (apart from a second increase in demand around Christmas). ${ }^{23}$

It is clear that the practice of kuziziritsa ku khosi allows smallholders to engage in practices from which they are usually excluded. Moreover, the ostentatious manner in which some smallholder growers purchase bottled beer and branded clothing suggests that these consumer practices are 
intended for a wide audience. But how can we understand such expenditure patterns and practices?

The starting point for an explanation is the observation that kuziziritsa ku khosi is a form of conspicuous consumption (Veblen i899). Veblen theorised that an individual's status in a society derives from others' interpretation of that individual's wealth. In other words, that it is not intrinsically what one has that makes one wealthy or poor, but how this compares to what others have. ${ }^{24}$ Veblen suggested two principal means through which individuals tend to display their wealth: first, the ability to participate in leisure activities (conspicuous leisure); and second, the extravagant purchase of goods and services (conspicuous consumption, which is our focus here). The main reason why these activities display wealth 'lies in the element of waste that is common to both' (ibid.: 85).

Veblen (ibid.) further theorised that consumer preferences are determined in a hierarchical manner according to social class. In other words, he posited that individuals emulate the consumer patterns of higher social classes (Campbell i995). In this formulation, individuals participate in leisure activities, or exhibit the symbols of financial wealth, to impress others and therefore 'gain their esteem or envy' (ibid.: 39). Importantly, Veblen (I899: 85) suggests that even the poorest social classes engage in the extravagant purchase of goods and services to display their wealth. For example, he notes that 'no class of society, not even the most abjectly poor, forgoes all customary conspicuous consumption. The last items of this category of consumption are not given up except under stress of the direst necessity. ${ }^{, 25}$

Veblen's understanding of conspicuous consumption has been widely criticised (Campbell I995; Trigg 200I). For example, the concept relies excessively on vertical downward transmission of consumer preferences (as opposed to horizontal, circular or upward transmission), and by focussing only on luxury goods it negates the importance of subtle forms of distinction (see Trigg 200I). Here, we focus on just one criticism: that the concept is unclear about whether the "operative motives should be viewed as conscious, subconscious, "instinctive" or merely embodied in habitual practices' (Campbell 1995: 45). In this respect, instead of trying to understand the practice of 'cooling off' as one of emulation, we can understand it as constituted, on the one hand, by unconscious, embodied and habitual practices which can be summarised as inculcated behaviour; and on the other, by conscious intentional 'action' imbued with subjective meaning (ibid.). ${ }^{26}$ Put simply, this paper suggests that smallholder growers' expenditure decisions and practices when 'cooling off' are partly an expression of inculcated behaviour. In other words, that these expenditure decisions reproduce the actions of black Malawian estate owners 
characterised earlier in the 'cultural model' of the tobacco bwana, because this is how some smallholder growers understand success. Indeed, focus groups who, at the end of the research process, were asked to explain why men engaged in the practice of 'cooling off', offered responses which support such an interpretation: ${ }^{27}$

Men when they have cash they rush to town to cool off leaving a wife at home without money. Men they feel that people who drink Carlsberg are people who have chuma (wealth), they feel like a rich person.

The tobacco growers want to spend money on [Carlsberg] green when they have received it as they want to revenge those who have been working on a salary all year and can enjoy every month end.

Farmers want to drink [Carlsberg] green to want to be able to show that they are bwanas.

But what are the consequences of such conspicuous consumption? The following two sections discuss this question by, first, comparing the attempts of two smallholder growers to finance and sustain a successful non-farm rural enterprise; and, second, describing limited data on how tobacco production and 'cooling off' are viewed by wives, and the crop preferences of both husbands and wives.

'COOLING OFF' AND TWO NON-FARM RURAL ENTERPRISES

The prevalence of 'cooling off' in the Central Region does not mean, of course, that most burley income is spent in this manner. On the contrary, data from the household survey suggest that this income is spent mainly on buying fertiliser and food, and also on clothing, household utensils, materials for household construction and repair, and repaying credit. But as the account of 'cooling off' above makes clear, kuziziritsa ku khosi limits the use of burley income for other, often more productive, purposes. To illustrate how 'cooling off' can, amongst other factors, have a detrimental influence on the success of household investments, this section compares the life histories of two smallholder burley growers who initiated successful non-farm rural enterprises. As indicated above, smallholder burley production was expected to boost the non-farm rural economy. The two cases presented here are rare examples of smallholder growers who managed to graduate into successful enterprise ownership, and compare the trajectory of one smallholder who 'cooled off' - Jejema Phiri - with that of one who did not-Macfield Msipu. Overall, the fortune of Mr Msipu contrasts strongly with the decline of Mr Phiri. ${ }^{28}$ The analysis which follows first details factors that have contributed to the success of both enterprises, 
before outlining how 'cooling off' was only one of the reasons for the failure of one of them.

\section{Case I - Macfield Msipu}

Macfield Msipu was born in 1973 in Lusaka, Zambia as the son of a sugar cane worker. He stayed in Lusaka until his parents divorced, when his mother took Macfield and his older sister to her village adjacent to a trading centre in Kasungu district. This was in 1989 when Macfield was sixteen years old. His sister soon married and moved to Mzimba district.

On his arrival in the trading centre, Macfield found some piecework with the Ministry of Agriculture, and used the payment to start selling usipa (dried fish), travelling to the lake at Nkhotakhota to buy supplies. In I993 he married, and from the proceeds of the fish business bought two pails of fertiliser and applied these to half an acre of burley tobacco. He yielded 3 bales and marketed these through a nearby estate. Macfield grew tobacco again the following year but failed to make a substantial profit. He withdrew his capital from tobacco production in 1995 and started buying goats, and later cows, to slaughter and sell on market days.

More importantly, Macfield also started smuggling goods across the border with Zambia. This was facilitated by his father's kin who lived in Lundazi district close to the border with Malawi. To start with he would take Maheu (a non-alcoholic millet beer) across to Zambia, and return with zitenje (materials) and shoes. He would travel using matolas (pick ups) but would avoid the customs post by taking tracks in the bush. He sold the goods to Asian traders in Kasungu town. As the smuggling business proved increasingly lucrative, he stopped working as a butcher.

In 1997 Macfield married a second wife and built a further house just outside his mother's village. The following year he started buying tobacco illegally at the trading centre and marketed it on the auction floors through an estate registration number. Trading in burley enabled him to move to the market in I999, where he opened a small grocery which was run by his first wife. Trading in burley also allowed him to start growing burley tobacco again, this time with a seasonal worker. Between 1999 and 2004 Macfield continued to grow and buy burley, and continued the lucrative trade across the border from Zambia to sell to the traders in town.

During the peak of the famine year of 2001/2, Macfield took a large gamble and travelled north to Tanzania. He returned in a truck with over I tonne of maize. In the famine in 2001/2 Macfield was a key source of maize for many people around the trading centre. Selling at Ioo kw per plate, at a time when a goat was selling for $5^{\circ} \mathrm{kw}$, and a bicycle for ${ }^{50} \mathrm{kw}$, 
he became wealthy. By the 2003/4 agricultural season, he was engaging seven workers to produce burley on communal land, in addition to his grocery and trading activities. Reflecting on his numerous business activities, Macfield felt that the most important business for him was the smuggling of goods across the border. This is where he claims that the capital came from to fund his other enterprises, such as trading in tobacco and maize. In response to the question whether he had any relatives who help him with his multiple enterprises, Macfield laughed. 'No,' he replied, 'ndili ndheka' (I am alone).

\section{Case 2 - Fejema Phiri}

Jejema Phiri was born in 1967 and grew up in Dowa district. He moved with his parents and brothers close to the same trading centre in I986, where they settled some distance from the main mudzi (village). In I99I Jejema married and began trading goats-buying from the Zambian border, and selling in the trading centre. He also farmed maize, groundnuts and a small amount of burley tobacco.

In I994 his uncle gave Jejema a loan to invest in burley production. With this injection of cash he expanded burley production and soon married a second wife. With capital and plenty of household labour, he started to lease unused communal land from neighbours in his village to expand his burley business. This was successful, and in I997 Jejema started to engage workers to grow burley for him on the land he was leasing. In the following three years he and his two wives managed a business with up to twelve workers farming on communal land. His expansion of burley production was conducted without any recourse to formal credit or loans. He bought all of his fertiliser with cash. As is common among smallholder burley farmers, he was fond of spending some burley income 'cooling off' in Kasungu town during the crop marketing season.

By 2000 Jejema had paid back the loan to his uncle, and purchased a second-hand minibus. With this he initiated the first minibus service to Kasungu town from the trading centre. By leaving earlier than the daily Stagecoach service, he ensured that the minibus was full on the first run to town. Not having a licence, he employed a friend as a driver, and worked as the conductor collecting fares from passengers. Back in the village his burley business was going strong and in the 2001/2 rainy season he applied more than seventy bags of fertiliser to his burley crop. However, this was the famine year. With all of his capital tied up in fertiliser, no savings, and with demand for his minibus business non-existent, in February 2002 Jejema was forced to borrow money from a local money lender to buy maize at famine 
prices to feed his extended family and workers. Even after buying maize, his extended family still had to resort to eating nsima ya ntochi (mealie from banana roots) to survive. Surprisingly, he managed to send over yo bales of burley to the auction floors in 2002. However, the poor quality of the leaf, reflecting the lack of care and attention paid to the plants, meant that he received very low prices. With the local money lender threatening punitive action, he was forced to sell the minibus at a highly discounted rate to supplement his auction floor income. Thus ended Jejema's dream.

In 2003 Jejema's wealthy uncle died, but he was unable to contribute to the funeral costs. The following agricultural season he and his wives did not engage any workers, did not grow any burley tobacco, but instead planted soya as a cash crop. Soon afterwards his second wife left him, and in the 2003/4 season he was growing groundnuts and trading in nyemba (beans) trying to build up the capital to start growing burley again.

The two cases presented here suggest a number of reasons why Macfield and Jejema were able to initiate successful non-farm rural enterprises. Three factors stand out. First, both are alendo (strangers). Macfield came to the area when he was sixteen, and does not have a close relationship with his mother's kin. This is shown geographically: his two houses were located far from the heart of the village. Jejema is also a mlendo (stranger) having moved to the area with his mother when he was nineteen. Again, both their houses are some distance from the main village.

Second, both Macfield and Jejema married twice. There can be little doubt that the successes of both businesses were to a large extent predicated on the labour of their respective wives. ${ }^{29}$ Both businesses also relied on hired labour: in Jejema's case this was by employing seasonal workers, and a friend to drive the minibus; for Macfield, his initial attempts at growing burley with his wife in 1993 and 1994 failed. It was only later, from 1999 onwards, when he employed a seasonal worker that he started to profit from burley production.

Third, both individuals relied on extended social relations to initiate a trajectory of accumulation. Macfield utilised his father's relatives and contacts in Lundazi district, Zambia, to initiate his smuggling business across the border. Jejema received a substantial loan from his wealthy uncle who lived in town. Without such assistance from kin, there is a fair chance that neither business would have become successful.

The cases also suggest that 'cooling off' was only one of the factors that contributed to the success of one business and failure of the other. Whilst Jejema was well known for spending time drinking in Kasungu town, other factors in these case histories appear much more significant. Two are highlighted here. First, the role of burley in the sequence of livelihood 
strategies. For Jejema, burley production was the basis on which his nonfarm rural business was founded. However, for Macfield, burley production was an outcome from numerous non-farm enterprises (especially smuggling and trading). In other words, burley production was an investment channel for Macfield's profits as opposed to a source of capital for his other enterprises. This is shown through his initial 'failure' in burley production prior to engaging a tenant. It is also illustrated by him marketing his burley via an estate registration number until 200I (if burley had been a key accumulation strategy, it is likely that Macfield would have joined a smallholder club, as the transaction costs are less in this marketing channel).

The second key factor was the impact of the chaka cha njala and control over food. Whilst Macfield generated substantial wealth by becoming an international maize trader, Jejema's production of burley tobacco came to an end as a result of borrowing money to buy maize. Jejema's actions resonate strongly with the wider experience of smallholder burley producers at his time: many disposed of assets at knock-down prices to feed not only their immediate family but also wider kin, and many rural households were forced into adverse coping strategies (see Bryceson 2006; Conroy 2005).

Overall, the two cases presented here suggest that whilst 'cooling off' may limit the use of burley income for other productive purposes, in most cases other factors (such as kin relations, the availability of labour, livelihood diversification and food prices) probably contribute to household accumulation or impoverishment to a greater extent. In this respect, it would be a mistake to attribute too much importance to the loss of capital that is part and parcel of 'cooling off'. We now turn to intrahousehold issues.

'C O OLIN G OFF' A N D INTR A-H O U S E H OLD R E L A T I ON S

To get an initial idea of how 'cooling off' was viewed by wives, semistructured interviews investigated the extent to which married women received a fair proportion of burley income. The results from these interviews were inconclusive. Therefore, questions about the intra-household distribution of burley income were included in the survey questionnaire conducted with wives. The responses to these questions are shown in Table 2, and are split into four categories: households in rural wage employment (Wage Always), all of whom were consistent tobacco growers; those which grew tobacco every year for the last three years (Always); those which grew tobacco twice in the last three years (Twice); those which grew tobacco once in the last three years $\left(\right.$ Once) ${ }^{30}$ 
TABLE 2

Intra-household distribution of tobacco income

\begin{tabular}{|c|c|c|c|c|}
\hline Are you happy that you are growing tobacco? & Wage Always & Always & Twice & Once \\
\hline Yes & 7 & 26 & I8 & I 5 \\
\hline No & I & I & I & I \\
\hline No answer & o & o & o & 4 \\
\hline $\begin{array}{l}\text { Do you receive money from your husband from } \\
\text { the tobacco sales? }\end{array}$ & Wage Always & Always & Twice & Once \\
\hline Yes & 6 & 20 & I4 & 9 \\
\hline No & I & 6 & 5 & 5 \\
\hline No answer & I & I & o & 6 \\
\hline $\begin{array}{l}\text { What do you spend the money from tobacco } \\
\text { sales on? }\end{array}$ & Wage Always & Always & Twice & Once \\
\hline Clothes & 5 & $2 \mathrm{I}$ & I2 & 8 \\
\hline Household items & 2 & 5 & 4 & I \\
\hline Hospital fees & o & I & o & o \\
\hline No answer & I & $\mathrm{o}$ & 3 & II \\
\hline $\begin{array}{l}\text { Are you happy with the amount of money } \\
\text { that your husband gives you? }\end{array}$ & Wage Always & Always & Twice & Once \\
\hline Yes & 5 & I4 & 9 & IO \\
\hline No & 2 & IO & 8 & 2 \\
\hline No answer & I & 3 & 2 & 8 \\
\hline $\begin{array}{l}\text { Have you ever taken any action to try and } \\
\text { increase the tobacco money that you get from } \\
\text { your husband? }\end{array}$ & Wage Always & Always & Twice & Once \\
\hline Yes & o & 4 & 6 & I \\
\hline No & 4 & I9 & IO & IO \\
\hline No answer & 4 & 4 & 3 & 9 \\
\hline
\end{tabular}

Source: Household survey.

Table 2 shows that wives across all four categories welcomed the production of burley tobacco, and that most wives received money after tobacco sales (and spent this mainly on clothes, and to a lesser extent on household items). But despite welcoming burley production, $37 \%$ of wives who responded stated that they were not happy with the amount of money given to them by their husbands. When asked directly whether the nonreceipt of tobacco monies led to any action, most wives stated that they had not tried to increase their personal gains from burley production (the eleven who had taken action asked for a greater share of income). In this respect, the research found no evidence to support the hypothesis that wives withdraw labour from, and support for, burley cultivation if they do not receive a fair proportion of income (which is certainly less likely if the husband spends income 'cooling off' in town). ${ }^{31}$

Wives' support for growing tobacco is particularly interesting, and is further illustrated by survey data that compares husbands' and wives' 

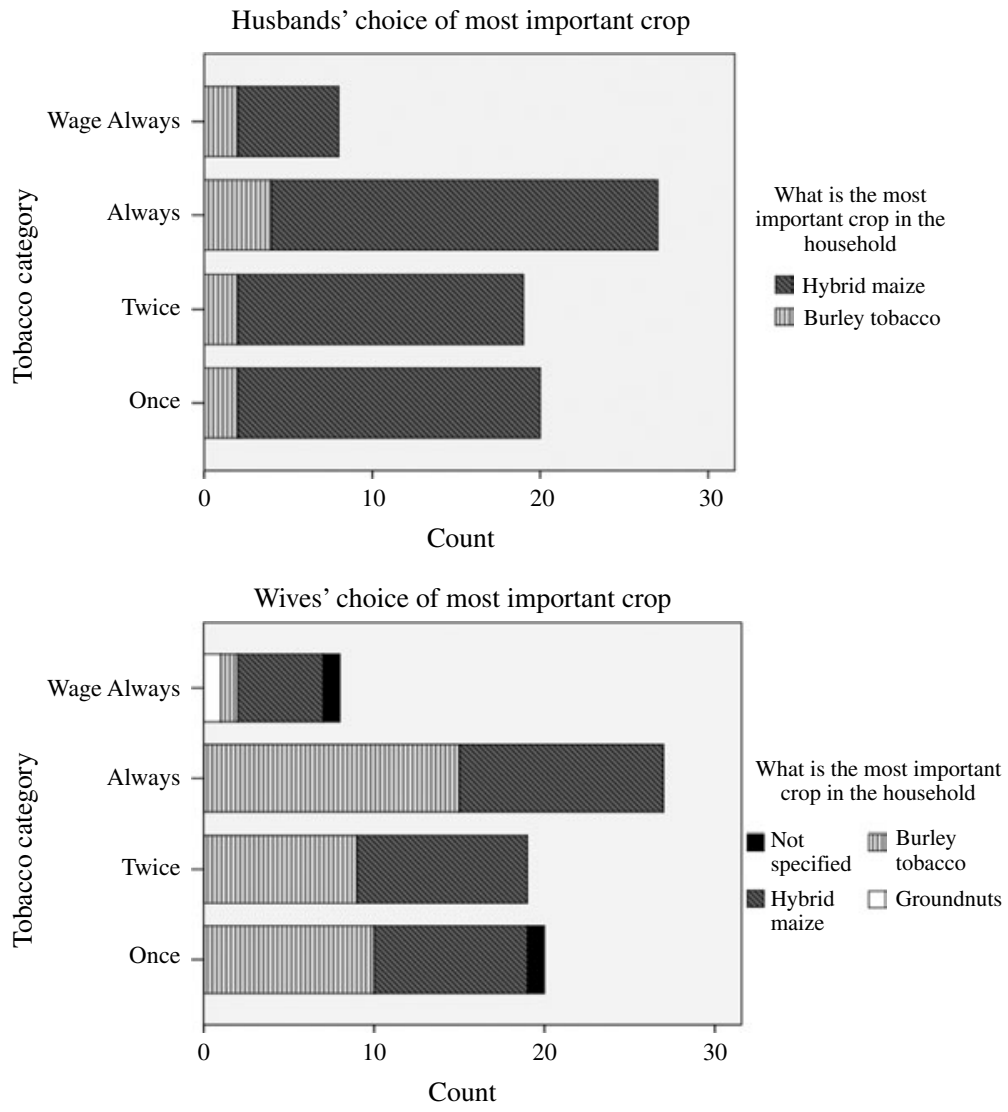

FI G URE 5

Husbands' and wives' choice of most important crop. Source: Household survey.

choice of the most important crop in the household. Figure 5 suggests that wives are much stronger advocates of burley production than their husbands, and vice versa regarding husbands' belief that maize is the most important crop. This finding conflicts with the commonly held view of male and female preferences for food and cash crops in Malawi (where cash crops are said to be male, and food crops female). To shed some light on possible reasons, at the end of the research process village focus groups were shown the above charts and were asked to interpret them. An extract from one discussion of the wives' chart is as follows:

Men (in unison):' Clothes'.

Husband I:'Women like tobacco so much because women like clothes .... They want to wear nice clothes!' 
Husband II:'Women need more clothes than men - they wear five or six at a time. So for them tobacco is important because of clothes!'

Wife r:'No. We like tobacco because after buying fertiliser and maize we can buy some household essentials. That is why we like tobacco.'

Wife II:'I asked my husband - why have you not started growing tobacco yet? I want things for the house and to have new zitenje (materials) and fashionable clothes. Tobacco can bring these things.'

Similar explanations were given by other focus group participants:

Wife:'Tobacco is the most important crop because when we grow tobacco and sell it we obtain money which we use it for growing maize and buying clothes. With maize we gain less profit after selling it. That's why we prefer growing tobacco.'

Wife:'Azimayi (women) say that tobacco is the more important crop because they get money for maize mill and to buy clothes.'

These focus groups corroborated some of the survey data. For example, that burley income is spent mainly on buying fertiliser and maize, and that wives tend to spend their portion of burley income on buying clothes and household essentials.

Overall, and in a similar fashion to section three, the final section of this paper presents data which suggests that it is important not to overstate the significance of 'cooling off'. In terms of the intra-household distribution of burley income, almost all wives appear to receive money from tobacco sales, and many spend this on clothes and on household items (including money for the maize mill). Moreover, almost all are happy to be growing tobacco, and wives are much greater advocates of burley production than their husbands. Such findings suggest that whilst 'cooling off' may divert resources from other productive purposes, it has not significantly reduced the gains that burley production has brought smallholder households. In other words, there is no contradiction between potlatch spending by husbands in Kasungu town and wives' support for burley production: even with extravagant consumer behaviour in Kasungu town, burley production appears to have generated sufficient income for wives to receive substantial benefits.

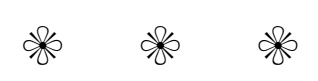

Although based on geographically limited fieldwork, the material presented here may have wider relevance, relating for example to debates on neo-patrimonialism in Malawi and elsewhere. Despite the shift from authoritarian rule to an ostensibly liberal democratic system of governance, politics in Malawi has been described as being influenced by 
neo-patrimonial and clientelist tendencies (see Booth et al. 2006; Cammack 2004). This is illustrated by the chameleon nature of politics in the democratic era (Englund 2002), where politicians change allegiance, or 'cross the floor' in parliament, frequently. A significant contribution to this debate is Lwanda's (2006) discussion of the role of achikulire (patrons or 'big men') in the Malawian polity. Lwanda argues that there are two main forms of achikulire in Malawi. First, the conventional rural/peasant achikulire embedded in village-level social, political and cultural hierarchies, who have very little traction over national-level politics; and second, the urban/ elite achikulire, based on the creation of patron-client political networks and trading activities, who have considerable power at the national level. Lwanda contends that by informally financing political activities, urban/ elite achikulire have become key power brokers and have stymied the emergence of young cadres of politicians who are independent of patronclient relations. ${ }^{32}$

One could interpret the practice of kuziziritsa ku khosi in Kasungu district through such a patrimonial lens: that the ostentatious consumer behaviour during the crop marketing season was aimed at fostering patron-client relations - for example, that 'cooling off' was a means for smallholders to temporarily shift status from a rural/peasant achikulire status to that of an elite/urban achikulire by creating clientelist networks via extravagant spending patterns. ${ }^{33}$ But such an interpretation forces an instrumental logic onto the lavish consumer behaviour which there are insufficient data to support. Nor does it account for the 'element of waste' that is an inherent element of 'cooling off' (that smallholders' consumer choices appeared profligate and decadent), and for the fact that such consumption appeared to be conducted for other people's benefit.

Instead, this article argues that 'cooling off' may better be understood as a form of conspicuous consumption, where smallholders display their ephemeral wealth to try to achieve the status of one model of success in this district - the tobacco bwana. Such an interpretation accounts for the 'waste' and performativity integral to the practice to a greater extent than a neo-patrimonial one.

Understanding 'cooling off' in this manner - as a search for status - may thus have some relevance for other apparently unintelligible investment decisions in the region, and in African economies more generally. Through the conspicuous nature of 'cooling off', we can see how wealth (and poverty) are intrinsically relational - that people compare what they have with what others have, particularly those whom they live near or work with (in other words, within reference groups). This competition between people in terms of income and status, referred to as a process of rivalry 
(Layard 2003), is part and parcel of our human nature, and is very much apparent in rural Malawi, as reflected in the names of groceries and other investments in Kasungu district: Njilu Ipinduranji (Jealousy brings you what benefit?); Ambili Sakondwera (Many people are not happy, i.e. with my wealth); Mudaranji? (Why do you hate me?). But, as Layard (2003) outlines, while rivalry between people in terms of status makes sense at the individual level (for it increases your rank above those around you), at the level of society as a whole it makes no sense: it is a zero-sum game because the total of rank is fixed.

In this respect, Veblen's (1899) work on conspicuous consumption, and the 'element of waste' at its core, offers an alternative perspective from which to view investment decisions which at first glance may appear incomprehensible and illogical, to the functional interpretation of neopatrimonialism where resources are misallocated through the creation of clientelist networks.

\section{NOTES}

I. A similar dynamic has occurred recently with leaf companies investing in flue-cured production in Malawi to replace shortfalls caused by political upheavals in Zimbabwe (see van Donge 2002a). For example, in the 2002/3 season Limbe Leaf signed a five-year deal to produce flue-cured tobacco on sixty-five Press Agriculture estates, and received special dispensation from President Muluzi to bypass the auction floors and to take the flue-cured leaf straight to their processing factories.

2. The 1973 Lome Convention, which gave duty-free access to European Community markets, contributed to the estate expansion in the mid and late i97os.

3. In some cases European estate owners were allowed to keep hold of one estate. For example, R. W. Wallace, one of the pioneers of large-scale tobacco export from the Central Region in the I930s, was allowed to keep a single estate. His fellow pioneer, A. F. Barron, had his estate holdings reduced from twelve to three. Others were less fortunate. I. Conforzi, a further significant figure in the history of tobacco in Nyasaland, lost all of his 12,00o acres in the Central Region (see McCracken I984).

4. Interestingly, when burley emerged as a crop of considerable potential in the I940s, it was planted on a trial basis on communal land (McCracken I984). However, it was reserved for estate-only production (along with flue-cured tobacco) in the I952 Tobacco Ordinance, which was reinforced by the I962 Africans on Private Estates Ordinance, and later by the 1972 Special Crops Act (Harrigan 200 ; ; Ng'ong'ola I986).

5. Smallholder burley production was expected to lead to increases in smallholder incomes, uptake of hybrid maize, application of fertiliser to maize, and diversification of smallholder cropping patterns, and to boost the non-farm rural economy (see Carvalho et al. I993; World Bank I994). This article only focuses on the first of these expectations.

6. To estimate smallholder production in the I99os, we need to account for the large amounts of smallholder-grown burley marketed through an intermediate buyer (IB) or estate registration number, in addition to smallholder sales on the auction floors. Figure 2 uses Auction Holdings datasets to produce an estimate of the amount of smallholder burley funnelled through estate and IB licences from I994 to 2003 , adds these to smallholder sales data, and compares this proxy figure to Jaffee's (2003) estimates. There is a high degree of similarity between the two production estimates, suggesting that these figures are a relatively accurate proxy for smallholder burley production. The assumptions used are identical to those in Jaffee's paper: that between 1994 and I998, 85\% of sales by intermediate buyers were smallholder-produced, and from 1999 onwards $95 \%$. The proportion of the recorded 'estate' sales in the auctions which originated on smallholder farms is estimated by Jaffee to have risen from $10 \%$ in 1994 to $\mathrm{I} 5 \%$ in $1995,30 \%$ in $1996,40 \%$ in 1997 , and $50 \%$ thereafter. 
7. Author's calculations from Auction Holdings datasets; see also Jaffee 2003.

8. Author's calculations from Auction Holdings datasets.

9. This reflects the importance of race as a structuring principle in the organisation of colonial economic and consumer practices (see Fanon I968; Kothari 2006; Mintz 1985).

IO. In February 2005 Stancom and Dimon merged to create Alliance One, which now competes with Universal Leaf (of which Limbe Leaf is a partially owned subsidiary) for primacy in the global tobacco leaf market.

I I. Until recently, tobacco processing and export in Malawi has been dominated by a cartel (most recently consisting of Limbe Leaf and Alliance One) that systematically depressed producer prices on the auction floors, carved up daily sales, and prevented the emergence of further export companies through their control of capital goods (i.e. processing equipment). In the last two years, this leaf company oligopsony has been challenged by the government in four ways. First, government rhetoric criticising the leaf companies has been matched by action - the work permits of key non-Malawian leaf company managers have been revoked; second, the government attempted (with limited success) to introduce minimum prices for grades of tobacco; third, the government-driven company, Malawi Leaf, designed to overcome the oligopsony, had some success in securing finance and overseas markets (particularly in Egypt); and fourth, and most importantly, a new international leaf merchant, Premium Leaf, has collaborated with the Tobacco Association of Malawi (TAMA) to create a new player on the auction floors. The emergence of Premium Leaf, a drop in burley production, and the potential of new markets in the East, contributed to burley prices in the 2007 marketing season being the highest for over a decade (over US\$3 per kg for very high-quality burley).

I2. There are, of course, exceptions. Flora Mpasanje at the Tobacco Control Commission is one example of a senior woman in the industry. The lack of women in the tobacco industry in Malawi contrasts with Zambia, where women work in numerous roles in the industry.

I3. ADMARC took over production on one of the three estates in about 2000. In 2003 Stancom, a tobacco leaf company, leased all three estates (as well as Chamwavi's other estate holdings) to expand flue-cured tobacco production using direct labour.

I4. The actions of many smallholders when receiving their income - drinking and socialising - are not so different from many groups of men across the region and globe. The significance in this case lies in the socio-historical basis of the practice, which contributes to its particular form and intensity, its public display, the element of waste inherent in it, and its incongruence with the material conditions in which many of the smallholders live.

I5. This household survey covered I27 households (I20 of whom farmed on communal land) in 4 villages spread over $25 \mathrm{~km}$ in rural Kasungu. The survey was conducted between January and April 2004, and $94 \%$ of households in the villages participated.

I6. To give an indication of the frequency of 'cooling off', husbands were asked: 'How many days did you spend in town when collecting your tobacco income?'

I7. In I998 Kasungu district held 96,787 households with an average household size of almost exactly 5 - a population of just under half a million (NSO 2000). Taking account of population growth (at $3 \%$ per annum) leads to an estimate of 115,569 households by 2004, and given that some of the population is urban (or does not farm on communal land), I0 \% of the smallholder population is about Io,ooo households.

I8. Interview with smallholder burley grower, TA Chamama, Kasungu District, May 2004.

I9. The symbolism of beer 'brands', particularly the association between bottled Carlsberg beer and social status in Kasungu, was confirmed by a number of informants in Kasungu district, and by observations.

20. The clothing of both older and younger smallholders sometimes included one incongruent element: a second-hand tatty old long jacket or trench coat, known as a scumba. Such jackets conflicted with the observed ostentatious and provocative consumer behaviour. So, what was the significance of these jackets? Initial attempts to elicit an explanation yielded little. For example, when I spoke to an agricultural extension worker about why he wore such a jacket, the response was to keep him warm whilst riding his motorbike (an answer with little relevance for smallholders). One answer to this riddle presented itself in a hardware store. To pay the cashier, a customer in a scumba reached into the lining to retrieve a brick of bank notes. One function of scumbas was to hide a large quantity of money. The scumba performed the same function for the agricultural extension worker, as he frequently carried large amounts of cash to finance crop purchases.

21. On the symbolism of clothing and style see Ferguson I999, Gondola I999.

22. When socialising with men in the rural trading centre and in Kasungu town, the use of prostitutes would frequently crop up in conversation. These conversations confirmed that the urban 
'style' exhibited by prostitutes in Kasungu in the crop marketing season increased their desirability for rural men. Conversations with smallholders also suggested that condom use amongst smallholder burley producers is not high - men would joke about how drinking too much alcohol not only encouraged the use of prostitutes, but would lead to the non-use of condoms. Needless to say, unprotected sex with prostitutes in Malawi is an extremely high-risk activity due to the risk of contracting HIV, and other sexually transmitted diseases (which in turn increase the chance of HIV infection).

23. Statistics gleaned from PSI in Lilongwe. Attempts to obtain comprehensive data foundered when I contacted PSI's head office in Blantyre.

24. Adam Smith expresses a similar belief in The Theory of Moral Sentiments.

25. Trigg (200I) argues that there are strong similarities between Veblen's (I899) work on conspicuous consumption and Bourdieu's (1977) theory of practice.

26. Whilst economic conduct is frequently seen as falling exclusively into the realm of 'action', Campbell (I995) highlights how some economic practices, due to habits and conventions, are redolent with 'behavioural' influence. These two elements combine to determine the way that consumer demand is constructed (see Friedman 1994).

27. Men and women gave similar responses.

28. These names are pseudonyms.

29. Macfield's grocery business certainly relied on his first wife's shopkeeping and inter-personal skills, and while Jejema was conducting his minibus business, his wives supervised the tenants growing tobacco.

30. The years referred to are the $2003 / 4,2002 / 3$ and the $2001 / 2$ agricultural seasons.

31. See Francis 2000, Heald I99I.

32. In this sense, Lwanda (2006: 526$)$ suggests that informally sourced capital 'may be more critical than ideology, social structures, ethnicity, religion, donors and other factors in retarding the development of Malawi's participatory democracy'.

33. Indeed, a previous version of this paper attempted to utilise Lwanda's (2006) distinction in this way.

\section{R E F E R E N C E S}

Booth, D., D. Cammack, J. Harrigan, E. Kanyongolo, M. Mataure \& N. Ngwira. 20o6. 'Drivers of change and development in Malawi', working paper 26r. London: ODI.

Bourdieu, P. 1977. Outline of a Theory of Practice. Cambridge University Press.

Bryceson, D. F. 2006. 'Ganyu casual labour, famine and HIV/AIDS in rural Malawi: causality and casualty', Fournal of Modern African Studies 44, 2: 173-202.

Cammack, D. 2004. 'Poorly performing countries: Malawi, 1980-2002', Background Paper 3 for ODI study on Poorly Performing Countries. London: ODI.

Campbell, C. 1995. 'Conspicuous confusion - a critique of Veblen's theory of conspicuous consumption', Sociological Theory I3, I: 37-47.

Carvalho, J., D. Gordon, D. Hirschmann, D. Martella \& E. Simmons. 1993. Mid-Term Evaluation of the Agricultural Sector Assistance Program (ASAP). Lilongwe: USAID.

Conroy, A. 1993. 'The economics of smallholder maize production in Malawi with reference to the market for hybrid seed and fertilizer', University of Manchester, unpublished PhD thesis.

Conroy, A. 2005. 'Poverty, AIDS and the food crisis', in S. Levy, ed. Starter Packs: a strategy to fight hunger in developing countries. Wallingford: CABI Publishing, 219-28.

Englund, H., ed. 2002. A Democracy of Chameleons: politics and culture in the new Malawi. Blantyre: Christian Literature Association in Malawi.

Fanon, F. 1968. Black Skin, White Masks. New York: Grove Press.

Ferguson, J. 1999. Expectations of Modernity: myths and meanings of urban life on the Zambian Copperbelt. Berkeley, CA: University of California Press.

Francis, E. 200o. Making a Living: changing livelihoods in rural Africa. London: Routledge.

Friedman, J. 1994. Consumption and Identity. Reading: Harwood Academic.

Gondola, D. 1999. 'Dream and drama: the search for elegance among Congolese youth', African Studies Review 42, I: 23-48.

Harrigan, J. 200I. From Dictatorship to Democracy: economic policy in Malawi, 1964-200o. Aldershot: Ashgate. 
Heald, S. I99.. 'Tobacco, time and the household economy in two Kenyan societies: the Teso and the Kuria', Comparative Studies in Society and History 33, I : 130-57.

Jaffee, S. 2003. Malawi's Tobacco Sector: standing on one strong leg is better than on none. Washington, DC: World Bank.

Kothari, U. 2006. 'An agenda for thinking about "race" in development', Progress in Development Studies $6, \mathrm{I}: 9-23$.

Kydd, J. I984. 'Malawi in the r970s: development policies and economic change', in Malawi: an alternative pattern of development. University of Edinburgh, Centre for African Studies.

Kydd,J. \& R. E. Christiansen. I982. 'Structural change in Malawi since independence: consequences of a development strategy based on large scale agriculture', World Development I7, 5: 355-75.

Kydd, J. \& A. Hewitt. I986. 'The effectiveness of structural adjustment lending: initial evidence from Malawi', World Development I4, 3: 347-67.

Layard, R. 2003. 'Income and happiness: rethinking economic policy', Lionel Robbins Memorial Lectures 2002/3, London School of Economics, 4.3.2003.

Lwanda, J. 2006. 'Kwacha: the violence of money in Malawi's politics, I954-2004', fournal of Southern African Studies 32, 3: 525-44.

McCracken, J. I983. 'Planters, peasants and the colonial state: the impact of the native tobacco board in the central province of Malawi', Joumal of Southern African Studies 9, 2: 172-92.

McCracken, J. I984. 'Sharecropping in Malawi: the visiting tenant system in the Central Province, c. I920-I968', in J. McCracken, ed. Malawi: an alternative pattern of development. University of Edinburgh, Centre for African Studies, I57-74.

Mintz, S. W. 1985. Sweetness and Power: the place of sugar in modern history. New York: Penguin.

Mkandawire, T. 2005. 'African intellectuals and nationalism', in T. Mkandawire, ed. African Intellectuals: rethinking politics, language, gender and development. London: Zed Books, $\mathrm{IO}^{-} 55$.

Mkandawire, R., S. Jaffee \& S. Bertoli. I99o. Beyond 'Dualism': the changing face of the leasehold estate sub-sector of Malawi. New York: Institute for Development Anthropology.

National Statistics Office (NSO). 200o. 1998 Malawi Population and Housing Census: report of final census results. Zomba: National Statistics Office.

Ng'ong'ola, C. I986. 'Malawi's agricultural economy and the evolution of legislation on the production and marketing of peasant economic crops', fournal of Southern African Studies 12, 2: 240-62.

Orr, A. 2000. "Green gold"? Burley tobacco, smallholder agriculture, and poverty alleviation in Malawi', World Development 28, 2: 347-63.

Orr, A. \& B. Mwale. 200i. 'Adapting to adjustment: smallholder livelihood strategies in southern Malawi', World Development 29, 8: 1325-43.

Orr, A., B. Mwale et al. 20or. 'Market liberalisation, household food security and the rural poor in Malawi', European Fournal of Development Research I3, I : 47-69.

Peters, P. E. I996. 'Failed magic or social context? Market liberalization and the rural poor in Malawi', Development Discussion Paper 562, Cambridge, MA: Harvard Institute for International Development.

Peters, P. E. I999. 'Agricultural commercialization, rural economy and household livelihoods I990-I997', Final Report to USAID, Lilongwe, Malawi.

Peters, P. E. 2006. 'Rural income and poverty in a time of radical change in Malawi', fournal of Development Studies 42, 2: 322-45.

Peters, P. E., M. G. Herrera et al. I989. 'Cash cropping, food security and nutrition: the effects of agricultural commercialization among smallholders in Malawi', Cambridge MA: Harvard Institute for International Development.

Rutherford, B. A. 200I. Working on the Margins: black workers, white farmers in postcolonial Zimbabwe. London: Zed Books.

Sahn, D. E. \& J. Arulpragasam. I99. Development through Dualism? Land tenure, policy and poverty in Malawi. Ithaca, NY: Cornell University Press.

Thomas, S. I975. 'Economic developments in Malawi since independence', Fournal of Southern African Studies 2, I: $3^{-} 5^{2}$.

Tobin, R.J. \& W. I. Knausenberger. 1998. 'Dilemmas of development: burley tobacco, the environment and economic growth in Malawi', Journal of Southern African Studies 24, 2: 405-24.

Trigg, A. B. 200I. 'Veblen, Bourdieu, and conspicuous consumption', fournal of Economic Issues 35, I : 99-II5.

USAID. I994. Malawi Agriculture Sector Assistance Program (ASAP) PAAD Amendment. Lilongwe: USAID.

van Donge, J. K. 2002a. 'Disordering the market: the liberalisation of burley tobacco in Malawi in the i99os', Fournal of Southern African Studies 28, I: 89-1 I5. 
van Donge, J. K. 2002b. 'The fate of an African "chaebol": Malawi's Press Corporation after democratisation', Fournal of Modern African Studies 40, 4: 65 I-8I.

Veblen, T. I899. The Theory of the Leisure Class: an economic study in the evolution of institutions. New York: Macmillan.

Whiteside, M. 1998. When the Whole is More than the Sum of the Parts: the effect of cross-border interactions on livelihood security in southern Malawi and northern Mozambique. Oxford: Oxfam GB.

Wilshaw, C. 1994. A Century of Growth: Malawi's tobacco industry, 1893-1993. Blantyre: Central Africana Ltd.

World Bank. 1994. Project Completion Report: Malawi-Agricultural Sector Adjustment Credit (Cr. 2I2I-MAI). Washington, DC: World Bank.

World Bank. 1997. Accelerating Malawi's Growth: long-term prospects and transitional problems. Washington, DC: World Bank.

Zeller, M. 1997. Growth Linkages of Smallholder Tobacco Production in Malawi. Washington, DG: World Bank.

Zeller, M., A. Diagne et al. 1998. 'Market access by smallholder farmers in Malawi: implications for technology adoption, agricultural productivity and crop income', Agricultural Economics 19: 2I $9^{-29}$. 